DOI: https://doi.org/10.34069/AI/2021.45.09.11 How to Cite:

Tarasenko, O., Shevchishen, A., Yermakov, Y., Mirkovets, D., \& Diakin, Y. (2021). Use of intelligence tools of operational and search activities in pre-trial investigation. Amazonia Investiga, 10(45), 105-112. https://doi.org/10.34069/AI/2021.45.09.11

\title{
Use of intelligence tools of operational and search activities in pre-trial investigation
}

\section{Використання інструментарію оперативно-розшукової діяльності у процесі досудового розслідування}

Received: August 16, 2021

Accepted: September 16, 2021

\begin{abstract}
The purpose of the article is to determine the features and legal grounds for the use of tools of operational and search activities in the pre-trial investigation. Subject of research: The subject of research is covert investigative (search) actions and operational and search measures. Methodology: dialectical method, formal logic methods, logical and semantic method, system analysis method, theoretical method, normative and dogmatic method, legal modeling method. The results of the study: Distinguishing between investigation and search measures, we apply the following principle: if the object of operational activities is already known to law enforcement officers we are talking about search measures, if not - about investigation measures. Practical consequences: The possibility of legal regulation of the use of tools of operational and search activity at the stages of criminal proceedings is determined. Value / originality: It is concluded that the list of operational and search measures also includes those that have no analogues with the CISAs and therefore operational and search
\end{abstract}

Анотація

Метою статті є визначення особливостей та правових підстав використання інструментарію оперативно-розшукової діяльності у процесі досудового розслідування. Предмет дослідження: Предметом дослідження $є$ негласні слідчі (розшукові) дії та оперативно-розшукові заходи. Методологія: діалектичний метод, методи формальної логіки, логікосемантичний метод, метод системного аналізу, теоретичний метод, нормативнодогматичний метод, метод правового моделювання. Результати дослідження: Проаналізовано зміст понять «пошук» i «розшук» 3 точки зору їх суттєвих відмінностей. Виокремлено оперативні пошукові та розшукові заходи із застосуванням принципу: якщо об'єкт оперативної діяльності вже відомий працівникам правоохоронних органів заходи розшукові, якщо ні - пошукові. Практичні наслідки: Визначена можливість правового регламентування використання

\footnotetext{
${ }^{37}$ Candidate of Legal Sciences, Associate Professor, Associate Professor of the Department of Operational and Search Activity of the National Academy of Internal Affairs (Kyiv, Ukraine).

${ }^{38}$ Doctor of Legal Sciences, Associate Professor, Professor of the Department of Criminal Procedure of the National Academy of the Internal Affairs (Kyiv, Ukraine).

${ }^{39}$ Candidate of Legal Sciences, Associate Professor (Kyiv, Ukraine).

${ }^{40}$ Candidate of Legal Sciences, Associate Professor, Associate Professor of the Department public law disciplines of Private Higher Education Institution «University of Modern Knowledge» (Kyiv, Ukraine).

${ }^{41}$ Candidate of Legal Sciences, Leading researcher of the scientific laboratory on crime prevention of the National Academy of Internal Affairs (Kyiv, Ukraine).
} 
measures do not duplicate the CISAs, but perform the task of ensuring the possibility of fulfilling the investigator's instructions to conduct the CISAs.

Key words: pre-trial investigation, operational and search activity, covert investigation (search) action, operational unit. інструментарію оперативно-розшукової діяльності за стадіями кримінального судочинства. Цінність / оригінальність: Робиться висновок про те, що до переліку оперативно-розшукових заходів, відносяться також ті, що не мають аналогів з НСРД і тому оперативно-розшукові заходи не дублюють НСРД, а виконують завдання забезпечення можливості виконання доручення слідчого щодо проведення НСРД

Ключові слова: досудове розслідування, оперативно-розшукова діяльність, негласна слідча (розшукова) дія, оперативнорозшуковий захід, слідчий, оперативний підрозділ.

\section{Introduction}

The Criminal Procedure Code of Ukraine (hereinafter - the CPC of Ukraine) (Law of Ukraine No. 4651-VI, 2012) has introduced the concept of "covert investigation (search) actions" (hereinafter - CISA) into the pre-trial investigation procedure, the system and methodology of which, even before the Code was approved, had been the subject of scientific debate. According to Art. 246 of the CPC of Ukraine, CISA is a kind of investigative (search) actions, information about the fact and methods of which are not subject to disclosure, except as provided for in the CPC of Ukraine. CISA, enshrined in Chapter 21 of the CPC of Ukraine (Law of Ukraine No. 4651-VI, 2012), in the nature and content of the activities carried out are correlated with the operational and search activities, enshrined in Part 1, Art. 8 of the Law of Ukraine "Operational and Search Activities" (Law of Ukraine No. 2135-XII, 1992); both types of activities are conducted in cases, in which information about the offense and the perpetrator cannot be obtained in any other way and only in criminal proceedings for serious or particularly serious criminal offenses. However, the detection, cessation and investigation of serious and especially serious criminal offenses (especially latent ones) without the use of tools of operational and search activities are extremely difficult or even impossible. Nowadays, scientists are only trying to balance the possibilities of investigation (search) measures and CISA with operational and search measures within a fundamentally new model of criminal justice, as well as to determine the boundaries, grounds and conditions of their application during criminal and investigative proceedings (Aidemskyi 2014, p. 18). The formation of the institution of CISA, which occurs in the operation of the current CPC of Ukraine, is characterized by a number of controversial issues operational units in the detection and investigation of criminal offenses. In particular, the Law of Ukraine "On Operational and Search Activities" (Law of Ukraine No. 2135-XII, 1992) measures, as well as the grounds and procedure for their implementation. This shortcoming is partially minimized by the list of rights of Law, which actually allows to understand that operational units have the right to conduct certain activities; however, it remains unclear, which of them are operative, and which belong to searching ones. Besides, there are references to the article of the CPC of Ukraine, which regulates a specific CISA, in most of the paragraphs of Art. 8 of the Law of Ukraine "On Operational and search Activities" (Law of Ukraine No. 2135-XII, 1992) (which specifies the rights of operational units); i.e. literally understanding the rule of law, the right of an operational unit can be realized only by conducting CISAs in criminal proceedings. Accordingly, the question arises: in such a case, the activity is a criminal investigation or the participation of operational units in the pre-trial investigation on behalf of the investigator? That is, there are a number of inconsistencies regarding the use of tools of operational and search activities - operational and search measures during the pre-trial investigation, which necessitates the determination of the peculiarities of the legal regulation for their implementation.

Thus, the purpose of the article is to determine the features and legal grounds for the use of tools that complicate the activities of investigative and does not contain the list of operational and search operational units, enshrined in Art. 8 of the above 


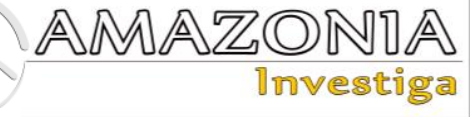

of operational and search activities in the pre-trial investigation

\section{Methodology}

The methodological basis for the Article is chosen given the goal, specifics of the object and subject matter of the research. The methodological basis for the article is dialectical approach to the determination of the features and legal grounds for the use of tools of operational and search activities in the pre-trial investigation. The formal logic methods of scientific knowledge (abstraction, analogy, deduction, induction, synthesis) help to clarify the legal nature of covert investigative (search) actions and operational and search measures.

Logical and semantic method is applied to reveal the meaning of the concepts of "search" and "investigation".

With the help of system analysis method the possibilities of legal regulation of the use of tools of operational and search activities at different stages of criminal proceedings are proposed.

Theoretical method makes it possible to study scientific literature on the issue under consideration.

Normative and dogmatic method is used to examine legal acts regulating to problem under investigation (Criminal Procedure Code of Ukraine, Law "On Operational and search Activity").

Legal modeling method is applied in the process of the features of covert investigative (search) actions and operational and search measures.

\section{Literature Review}

The scientists, who studied the issue under consideration, noted a number of problematic issues. For example, Tatarov (2013, p. 15) noted the uncertainty of the ratio and boundaries of operational and search measures and CISAs, namely: a problem in criminal proceedings is the conduct of such CISAs as audio and video surveillance of a person (Article 260 of the CPC) (Law of Ukraine No. 4651-VI, 2012); withdrawal of information from transport telecommunications networks (Article 263 of the CPC) (Law of Ukraine No. 4651-VI, 2012), because they should be preceded by investigation (search) actions aimed at identifying persons, as the permission to interfere in private communication is granted by the court only in respect of a particular person (this leads to a lengthy collection of information on such persons, therefore there is a risk of information leakage on the intentions of law enforcement agencies to expose this activity); besides, it is formally prohibited to carry out operational and search measures in criminal proceedings.

Karnaukh (2018, p. 164) states that the Supreme Court of Ukraine adheres to the position according to which the operational and search proceedings are limited to the preparatory stage of the crime; in case of an attempt or a completed criminal offense criminal proceedings should be carried out.

Pohoretskyi and Serheieva (2014, p. 138) prove that in contrast to the CISAs, the list of which is defined directly in Chapter 21 of the CPC of Ukraine (Law of Ukraine No. 4651-VI, 2012), certain operational and search measures, their grounds and procedure, providing results to the agencies conducting criminal proceedings, are enshrined in separate bylaws, which are not available to all actors of criminal procedure.

A number of other scientists believe that the practice has just begun to work out tactics for operational and search measures under current CPC of Ukraine and therefore, exploring the theoretical aspects of the application of these measures and CISAs in the new criminal procedure legislation, there was no opportunity to analyze the practice of their application. We partially considered this issue in the study of the process of formation of the institution of CISAs in the criminal justice system of Ukraine, resulting in the conclusion that: on the one hand, the use of CISAs results in criminal proceedings differs from similar simplified mechanism that eliminates the need for additional legalization and promotes the efficiency of the use of documents drawn up as a result of covert investigation (search) actions, but on the other hand - the lack of clear regulation of these procedures directly in the CPC of Ukraine significantly reduces the effectiveness of their implementation and use of the results obtained (Tarasenko et al. 2021, p. 469).

Thus, aim of the article is to determine the features and legal grounds for the use of tools of operational and search activities in the process of pre-trial investigation.

\section{Results and Discussion}

Investigation (search) actions are procedural actions regulated by the criminal procedure law, 
aimed at collecting, recording and verifying evidence. The criteria for classifying any procedural actions are: their cognitive orientation, i.e. the focus on collecting, recording and verifying evidence; the procedural form provided by law, in accordance with which investigative actions are carried out; the possibility of violation of rights and legitimate interests of persons, that's why some of them are carried out only after the permission of the court or with the sanction of the prosecutor; the possibility of using State coercion in their conduct.

CISAs do not fully meet these criteria, as they are operative in nature. According to the CPC of Ukraine, the possibility of using the CISAs is provided for the detection of the vast majority of criminal offenses, and, first of all, serious and especially serious ones. That is, the current criminal procedure legislation had led to changes in regulations governing operational and search activities, as a result of which operative measures in documenting the actions of criminals have obtained new specifics. According to Art. 41 of the CPC of Ukraine (Law of Ukraine No. 4651VI, 2012), operational units carry out CISAs in criminal proceedings on behalf of the investigator, prosecutor. Although, during the execution of these instructions the officer of the operational unit uses the powers of the investigator, but the employees of the operational units do not have the right to carry out these actions in criminal proceedings on their own initiative or to apply to the investigating judge or prosecutor. That is, on the one hand, operatives have the powers of investigator and on the other hand - this authority is truncated. Besides, operational units practically carry out operational and search measures when conducting CISAs, exercising their rights in accordance with the requirements of the Law "On Operational and Search Activities" (Law of Ukraine No. 2135XII, 1992).

We note the logical and semantic mistake in the defined ratios of operational and search measures and SICAs. Operational measures include the collection of information about the planned crimes, the behavior of specific individuals, the causes of certain crimes that require immediate action (Khyzhniak, Khankevych, Nazarenko, Pleskach, \& Tretiak 2021, p. 39). In practice, operational search lies in obtaining primary information and its verification. There is a need to take a number of measures in the process of detecting criminal offenses in the absence of all elements of the criminal offense - this is due to the specifics of committing latent criminal offenses (at the time of commission of a criminal offence, a person may commit a number of legal acts, therefore, it is also impossible to claim that a person is preparing to commit criminal acts).

According to the Law of Ukraine "On Operational and Search Activities", this activity should be carried out within the established operational and investigative case, and only the availability of sufficient information obtained in the manner prescribed by law, which requires verification by operational and investigative measures is the basis for its initiation (Shapovalov 2015, p. 175). Therefore, the Law of Ukraine "On Operational and Search Activities" allows to exercise the rights of operational units with the use of separate, clearly defined measures. Besides, when planning measures to verify primary operational information, it is necessary to take into account the possibility of drawing a clear line between information verification and documentation of criminal activity, as in the course of certain operational and search measures aimed at verifying primary information, criminal actions will be recorded. Shapovalov (2015, p. 175) notes that in fact, the measures of operational search ensure the implementation of the rights of operational units also when a check is made prior to the establishment of a criminal investigation file.

Formally, operational and search activities consist of a system of transparent and covert search and counter-intelligence activities carried out using operational and operational and technical means. Note that there are no "search measures" in this list of measures. Instead, the semantics of the term "covert investigative (search) actions" emphasizes that the actions are "investigative", although these actions take place in the course the criminal process and the investigator does not search in the literal sense of the term, but gives instructions to operational units; in turn, they shoud exercise their rights to conduct operational and search measures during the execution of this order. One could suggest that investigative and search activities are one and the same. But the concepts of "investigation" and "search" have quite different meaning.

These differences lie in the degree of uncertainty of the subject's knowledge of object being searched. When searching, the initial image of a person, material object, trace is revealed in the mind of the subject (investigator, operative) in the form of a plausible model of his (her) image, skills, properties and condition. When searching for specific features of the wanted object, the 


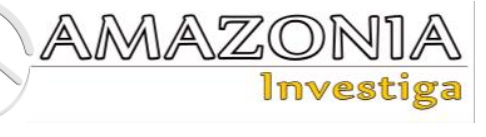

search ends with the identification of the wanted object; thus, the information on the identification features of the wanted person or object (identification tasks are solved after identifying the object) is of great importance for a successful search. Effective search requires knowledge of the traceability of a certain class(s) of offender, material objects, traces in the environment or in the environment that contributes to concealment.

Search is an independent activity of law enforcement agencies to identify persons and objects related to a criminal offense, which is carried out in a relatively unlimited space and time. Obraztsov (1992, p. 45) notes that the search is a method of procedural or nonprocedural activities, including covert ones, aimed at identifying the sources (carriers) of the information relevant to criminal proceedings. At the same time, it is correctly noted that search activity "is a necessary attribute, an important basic chain, an element of each stage of the investigation".

This position, in our opinion, needs to be clarified, as the detection of a perpetrator, other object or its search are independent, but organically interconnected functional areas in the detection of criminal offenses. When searching for the image of a person, a material object is presented in the mind of the subject (operational worker) in the probabilistic model and for effective search requires knowledge of the traceability of a certain class(s) of offender, material objects, traces in the environment or in the environment that contributes to concealment. Therefore, search is exclusively a process of operational and search activity. The researchers note that the level of search activity, the degree of "saturation" of search operations and activities of each of the traditional stages of the investigation process are different. The same conclusion can be made by analyzing the stages of disclosure of a criminal offense. Thus, at the beginning of the activity of the operational officer, it is of clearly search nature. At the next stage, provided that the search component is preserved, the main feature is the information and research orientation, that is, checking the primary information. With regard to the final stage, the activity is mainly procedural and systematizing in nature (transfer of materials to the investigative unit, provided that a criminal offence is being committed or has been committed; the establishment of operational and investigative cases and further operational proceedings). Besides, operational units are obliged to continue the search activity, due to the fact that it allows covert methods and means to obtain new information about episodes, accomplices or other circumstances that were previously unknown - that is, it is "search" and not "investigation".

That is, distinguishing between investigation and search measures, we apply the following principle: if the object of operational activities is already known to law enforcement officers we are talking about search measures, if not - about investigation measures. This gives grounds to assert the following: since the definition of operational and search activities does not contain such a component as investigative measures, but instead it is present in the term "covert investigative (search) actions", and operational units perform such activity independently (without the investigator's instructions), it should be called "operational and search activity". The search for persons performed within the pre-trial investigation after the beginning of criminal proceedings; if CISAs are used in the process of its application, then operational units, searching for a person on behalf of the investigator or conducting other CISAs, participate in pre-trial investigation operational search activities, identifying persons and facts of operational interest.

In addition to terminology, there are a number of problematic issues and inconsistencies in the legal regulation of operational and search measures, which significantly affect the effectiveness of combating criminal offenses and their investigation. In this regard, Bahanets (2012) notes that despite the significant differences between procedural evidence and evidence obtained as a result of CISAs and operational and search measures, the CPC of Ukraine actually combines operational and search activities and pre-trial investigation, giving the investigator uncharacteristic powers to conduct CISAs. The scientist believes that these activities have been carried out, are being carried out and should be carried out in the future only by specially authorized operational units that have the appropriate special tools, and most importantly - proper training, knowledge and skills. Partially agreeing with this opinion, we note that, indeed, operational units conduct operational and search measures both before the criminal proceedings and during the pre-trial investigation. But at each of these stages there are issues of legal admissibility of operational and investigative measures.

Nowadays, the procedure for obtaining information from official sources on the fact of committing criminal offense with registration in 
the Unified Register of pre-trial investigations and the beginning of criminal proceedings is clearly defined. However, a radically different situation occurs when the fact of committing a specific criminal offense is unknown, but, for example, there is information about the preparation for its commission on the basis of indirect signs (Vardanian 2015, p. 64). The latency of a significant part of criminal offenses leads to the absence of official statements and notifications, so one of the grounds for registration of information about the commission of a criminal offense in the Unified Register of pre-trial investigations is the detection of its signs by operational units. Operational officers receive primary information, which does not contain signs of all elements of the criminal offense. That is, it may be a subjective opinion of the operational officer on the possible signs, rather than the actual facts that indicate the commission of a criminal offense. However, it is necessary to pay attention to the wording of Part 2 of Art. 7 of the Law of Ukraine "On Operational and Search Activities" (Law of Ukraine No. 2135-XII, 1992), which states that in case of detection of signs of a crime, the operational unit should immediately send the collected materials (which recorded factual data on illegal actions of individuals and groups, the liability for which is provided by the Criminal Code of Ukraine) to the relevant body of pre-trial investigation to initiate and conduct a pre-trial investigation. That is, there is a logical discrepancy between the content (in terms of proof) of the identified "signs of a criminal offense" and "factual data", which cannot be established "immediately". Considering the meaning of the term "fact of a criminal offense" it is clear that its use requires the presence of all elements of the criminal offense (object, objective aspect, subject, subjective aspect), without which it is impossible to talk about the fact of a criminal offense, but only about its individual features (Shapovalov 2015, p. 137).

But since the current legislation does not provide for such an inspection, the operational units use the opportunities provided by Part 3, Art. 7 of the Law of Ukraine "On Operational and Search Activities" (Law of Ukraine No. 2135-XII, 1992), which states that if the signs of an offense are detected in the course of ongoing operational and search measures, the termination of which may adversely affect the results of criminal proceedings, the unit that carries out such activities notifies the relevant body of pre-trial investigation and the prosecutor on detection of the signs of a crime, completes these measures, and sends the collected materials (which recorded factual data on illegal actions of individuals and groups, the liability for which is provided by the Criminal Code of Ukraine) to the relevant body of pre-trial investigation.

At the next stage (in the course of investigation) the investigator helps operation officers to carry out the necessary in such cases CISAs, search and detention of certain persons. A number of operational and search measures are performed after registration of an offense in the Unified Register of pre-trial investigations within criminal proceedings in the implementation of the CISAs. That is, in the presence of all necessary grounds (Nykyforchuk, Tarasenko, Lyzohubenko 2015, pp. 7 - 20) and the investigator's order, the operational unit exercises its right by conducting both CISAs and operational and search activities, which do not require a court permission (decision) (for example, interviewing individuals with their consent). When executing orders for conducting CISAs, a necessary precondition for their implementation is the prior secret collection and verification of information about the person in respect for whom the CISA is planned, or other objects, information about which is necessary for their effective implementation.

The problem with obtaining such information is that the activities during active receipt involve interference with a person's private life, but remains outside the legal regulation of the CPC of Ukraine. That is, on the one hand, the measures to obtain such supporting data are not procedural (because they are not regulated by the CPC), and on the other one - they are not formally operational and search (because they are carried out during criminal proceedings); therefore the question arises as to the validity of such actions, as they are carried out before the decision of the investigating judge. Part 3, Art. 8 of the Law of Ukraine "On Operational and Search Activities" (Law of Ukraine No. 2135XII, 1992) determines the possibility of carrying out investigative measures in accordance with the decision of the of the head of the body, operational unit or his (her) deputy, authorized to perform them, informing the prosecutor of the decision taken.

The scientists consider operational and investigative activities within certain blocks, distinguishing the legal justification for each of them (Nykyforchuk, Kravchenko, Kopylov 2013 , pp. $175-176)$. Taking into account these views, we interpret the possibility of legal regulation of the use of tools of operational and 


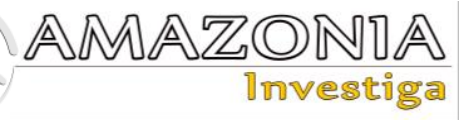

search activities at the following stages of criminal proceedings, namely:

at the stage of detection of criminal offenses a number of operational and investigative measures are aimed at obtaining primary information, the legal basis for which is Art. 7 of the Law of Ukraine "On Operational and Search Activities", which states that operational units are obliged to take the necessary operational and investigative measures within their powers on timely detection of crimes. Analyzing the logic of the legislator, it becomes clear that when the operational unit reveals the actual data about the commission of a criminal offense (and not some of its features), it transfers this information to the relevant body of pre-trial investigation;

the legal basis for conducting operational and search measures at the stage of obtaining primary information (which requires verification) about a criminal offense that is being prepared or a person who is preparing to commit it is Art. 8 of the Law of Ukraine "On Operational and Search Activities" (Law of Ukraine No. 2135-XII, 1992) (the rights listed in the paragraphs, which contain a reference to the specific article of the CPC, can be exercised only by conducting CISAs);

at the stage when the information about the criminal offense that is being prepared or the person who is preparing to commit it is confirmed, the legal basis for conducting operational and search measures is Art. 6 of the Law of Ukraine "On Operational and Search Activities" (Law of Ukraine No. 2135-XII, 1992), which directly indicates the possibility of conducting operational and investigative measures, as well as Art. 9 of this Law, according to which an operational and search case is opened against the person suspected of preparing to commit a criminal offense; against unidentified persons who are preparing to commit it, as well as against the persons, for whom there is evidence of participation in the preparation of the commission.

at the stage of pre-trial investigation in criminal proceedings in the presence of all necessary grounds and instructions of the investigator, the operational unit exercises its rights listed in Art. 8 of the Law of Ukraine "On Operational and Search Activities" (Law of Ukraine No. 2135XII, 1992) (which contain a reference to a specific article of the CPC of Ukraine), by conducting CISAs in the manner prescribed by the CPC of Ukraine. Besides, Part 3, Art. 8 of this Law determines the possibility of performing operational and search measures by the decision

of the head of the body, operational unit or his (her) deputy, authorized to perform such activities informing the prosecutor of this decision. In the future, the protocol and material media of classified information obtained during the search operations may be declassified and transferred to the pre-trial investigation bodies or the court if they hold factual data that can be used in criminal proceedings (as the basis for initiating criminal proceedings or conducting urgent investigative (search) actions and CISAs.

\section{Conclusions}

Thus, operational and search activities can be carried out both before the pre-trial investigation and simultaneously; operational and search measures can be initiated before the pre-trial investigation and terminate during its conduct; operative and search measures do not terminate with the beginning of criminal proceedings, but continue further obtaining a different status; performing operational and search measures is aimed not only at fixing the facts of criminal offenses that are being prepared or the criminal actions of persons who are preparing to commit them, but also solves a number of other tasks in the course of pre-trial investigation; the list of operational and search measures also includes those that have no analogues with the CISAs and therefore operational and search measures do not duplicate the CISAs, but perform the task of ensuring the possibility of fulfilling the investigator's instructions to conduct the CISAs.

\section{Bibliographic references}

Aidemskyi, E. (2014). Activities of operational units to detect and cease crimes in the gambling business. Law Forum, Num. 1, pp. 16-34. http://webcache.googleusercontent.com/sear ch?q=cache:HWuT3GmjazQJ:irbisnbuv.gov.ua/cgibin/irbis_nbuv/cgiirbis_64.exe\%3FC21CO M\%3D2\%26I21DBN\%3DUJRN\%26P21DB N\%3DUJRN\%26IMAGE_FILE_DOWNLO AD\%3D1\%26Image_file_name\%3DPDF/F P_index.htm_2014_1_3.pdf $+\& c d=2 \& h l=r u$ $\& \mathrm{ct}=\mathrm{clnk} \& \mathrm{gl}=\mathrm{ua}$

Bahanets, O. (2012). Advantages and disadvantages of the new Criminal Procedure Code. Proposals for amendments to the new Criminal Procedure Code of Ukraine. http://baganets.com/blogs-

baganets/perevagi-ta-nedol-ki-novogokpk.html.

Karnaukh, S. (2018). Urgent investigative (search) actions and operational and search 
measures: the issues of theory and practice. University Scientific Notes, No. 66, pp. $159-166$.

Khyzhniak, Y., Khankevych, A., Nazarenko, I., Pleskach, O., \& Tretiak, O. (2021). Model of operational search prediction of intentional homicide by criminal police. Amazonia Investiga, 10(40), pp. 37-44. https://doi.org/10.34069/AI/2021.40.04.4. https://amazoniainvestiga.info/index.php/am azonia/article/view/1595/1638

Law of Ukraine No. 2135-XII. About operational search activity. Official Web site of the Verkhovna Rada of Ukraine, April 13, 2012. Available online. https://zakon.rada.gov.ua/laws/show/213512\#Text

Law of Ukraine No. 4651-VI. Criminal Procedure Code of Ukraine. Official Web site of the Verkhovna Rada of Ukraine, April 13, 2012. Available online.

https://zakon.rada.gov.ua/laws/show/465117\#Text

Nykyforchuk, D., Kravchenko, A., and Kopylov, A. (2013). Problematic issues of operational and search measures and covert investigative (search) actions. Scientific Bulletin of the NAVS, No. 4, pp. 173-181.

Nykyforchuk, D., Tarasenko, O., and Lyzohubenko, E. (2015). Covert investigative (search) actions: textbook with structural and logical schemes. Kyiv: National Academy of Internal Affairs.

Obraztsov, V. (1992). Forensic support of the preliminary investigation. Moskow: Jurist.

Pohoretskyi, M., and Serheieva, D. (2014). Covert investigative (search) actions and operational and search measures: the concept, essence and relationship. Fight against organized crime and corruption (theory and practice), 2(33), pp. $137 \quad-166$. http://nbuv.gov.ua/UJRN/boz_2014_2_34

Shapovalov, O. (2015). Operational search for the signs of latent crimes in the sphere of economic activity. Prykarpattia Legal Bulletin, 3(9), pp. 183 - 187. http://www.pjv.nuoua.od.ua/v32_2015/42.pdf

Tarasenko O., Tsutskiridze M., Shevchishen A., Yermakov Y., \& Mirkovets D. (2021). Establishment of the institution of covert investigation in the criminal justice system of Ukraine. Cuestiones Politicas, 39(69), pp. $462-474$.

Tatarov, O. (2013). Problems of pre-trial investigation of gambling // In the collection: Actual problems of investigation of crimes under the new Criminal Procedure Code of Ukraine of All-Ukrainian scientific and practical conference (Kyiv, July 5, 2013). Kyiv: National Academy of Internal Affairs, p. 13-16.

Vardanian, H. (2015). Methods of investigation of crimes related to the production and treatment of non-compliant licensing and (or) falsified, substandard, unregistered drugs, medical devices or biologically active additives. (PhD Dissertation). Tula State University, Russian. https://xn--h1ap6b.xn-b1aew.xn--

p1ai/upload/site138/document_file/CS0pDM rfvE.pdf 